\title{
An attempt to identify factors determining the prevalence and intensity of depression in patients with diabetes in Polish population - preliminary report
}

\section{ABSTRACT}

Introduction. Diabetes is included in the group of metabolic diseases. According to the estimates of the World Health Organization (WHO) the global number of patients suffering from diabetes has increased to 387 million in just 11 years. $5 \%$ of Polish society, which is about 2 million, is diagnosed with this particular illness in Poland. Metabolic disorders occur 2 to 3 times more often in patients with mental diseases than in the general population. Often diabetes is accompanied by depression making it a chronic illness.

Aim. The aim of the study is to identify factors determining the prevalence and intensification of depression in patients suffering from diabetes.

Material and methods. The study included 100 patients with diabetes in the Subcarpathian region, who are being treated in specialist clinics. The study was conducted from $12^{\text {th }}$ to $20^{\text {th }}$ April 2016 using an original questionnaire. Verification of differences was performed by means of chi-square test of independence and $U$ Manna-Whitney test, applying the significance level at $p<0.05$. Calculations were performed using SPSS.

Results. The average age of the respondents was 41.25 years, SD $=15.38$. The prevalence of depression in family history was pointed by $31 \%$ of responders and

Address for correspondence:

dr Dorota Ozga

Katedra Ratownictwa Medycznego, Uniwersytet Rzeszowski

ul. Pigonia 6, 35-959 Rzeszów

Phone: +48 (17) 8721195

e-mail: gdozga@poczta.fm

Clinical Diabetology 2016, 5, 5, 141-146

DOI: $10.5603 /$ DK.2016.0025

Received: 12.10.2016

Accepted: 23.11.2016
$40.0 \%$ of them declared permanent psychiatric consultations. Depression was diagnosed in $\mathbf{2 5 . 0 \%}$ of the diabetic patients. Among the symptoms observed the respondents enumerated fatigue, lack of energy, lack of motivation to make any effort $(60.0 \%)$. Depression was treated more often among patients treated for diabetes for over 20 years (53.8\%).

Conclusions. The prevalence of depression symptoms was observed by all of the patients in the study. The most common ones included fatigue, lack of energy and lack of motivation to make any effort. More men than women stated that they were consulting a psychiatrist. The patients who suffered from diabetic complications are more eager to consult a psychiatrist and undergo the treatment for depression. Fluctuations of blood glucose may have an impact on depression symptoms in diabetic patients. (Clin Diabetol 2016; 5, 5: 141-146)

Key words: diabetes mellitus, depression, depression symptoms, insulin, hemoglobin A1c, diabetic complications

\section{Introduction}

According to the estimates of the World Health Organization (WHO) the global number of patients suffering from diabetes has increased to 387 million in just 11 years (2003-2015). This means that the number of people with diabetes doubled [1] and 55\% increase to 592 million in 2035 is forecasted [2]. It is estimated that $5 \%$ of Polish society, which is about 2 million, is suffering from diabetes, including nearly $50 \%$ of still 
undiagnosed and consequently untreated patients. Additionally it is evaluated that almost $10 \%$ of Polish population (4 million people) is considered as a group of people with pre-diabetic, which has a similar pathogenic meaning as diabetes itself. In Poland diabetes is still the main cause of blindness among adults, kidney failure and limb amputation [3].

In the recent decades it has been observed that the number of patients with depression has increased significantly. Around $15 \%$ of Polish population suffers from depression, including women being at a twice as high risk of depression than men (women - 20\%, men - 10\%) [4]. Metabolic disorders in patients with mental diseases (schizophrenia, bipolar affective disorder, depression) occur 2-3 times more often than in the general population. Particularly often depressive disorders accompany diabetes constituting a classic example of a chronic disease. It has been proved that the risk of depression in the population suffering from a chronic disease is amounted to $4 \%$, whereas in the general population it is $2.8 \%$ [5].

More than $11 \%$ of patients suffering from diabetes comply to the criteria to be diagnosed with depression, however $31 \%$ of the sick ones experiences individual symptoms. The prevalence of depression in patients with diabetes is definitely higher among women than men $(28 \%$ vs. $18 \%, p<0.0001)$ [6]

The aim of the work is to identify the factors determining the prevalence and intensification of depression symptoms among patients suffering from diabetes.

\section{Material and methods}

The study included 100 patients with diabetes from the Subcarpathian region, who are being treated in specialist clinics. The study was conducted from $12^{\text {th }}$ to $20^{\text {th }}$ April 2016 using an original questionnaire. Verification of differences was performed by means of $\chi^{2}$ test of independence and Manna-Whitney test, applying the significance level at $p<0.05$. Calculations were done using SPSS.

\section{Results}

The study group consisted of 61 women and 39 men in mean age $41.25 \pm 15.38$ with the minimal age of 17 and maximum age of $79.36 \%$ of the patients were aged $17-30,34 \%$ were $31-50$ years old and $30 \%$ were 51-79 years old. The average time of diabetes duration was $16.8 \pm 13.20$ years. The prevalence of depression in family history was pointed by $31 \%$ of the respondents. $38 \%$ suffered from type 1 diabetes mellitus (T1DM), 23\% - type 2 diabetes mellitus not taking insulin (T2DM), 32\% - type 2 diabetes mellitus taking insulin (T2DM) and 7\% of gestational diabe- tes. Majority of the respondents (64\%) was treaded with insulin. All of the patients in study declared that they use glucometers to measure blood glucose. The average level of satisfaction with physicians' care in the diabetic clinic was $4.36 \pm 1.18$ on a scale from 1 to 5 points and it was assessed as high. The average level of satisfaction with nursing care in the diabetic clinic was $4.24 \pm 1.28$ on a scale from 1 to 5 and it was high as well. The average upper glucose level was $224.54 \pm 69.75 \mathrm{mg} / \mathrm{dL}$. The result varried between 115 to $400 \mathrm{mg} / \mathrm{dL}$ and half of patients had upper range of daily glucose level below $200 \mathrm{mg} / \mathrm{dL}$. $49.0 \%$ of the respondents stated that they had $\mathrm{HbA}_{1 \mathrm{c}}$ tested in the last year. 44 people from this group had the $\mathrm{HbA}_{1 \mathrm{c}}$ measurement performed. Average level of $\mathrm{HbA}_{1 \mathrm{c}}$ was $6.81 \pm 1.11$ and the results fitted into a range of 5.0-10.0 with a half of the measurements being less than $7.26 \%$ of the patients in the study did not measure the $\mathrm{HbA}_{1 \mathrm{c}}$ level in the previous year and $25 \%$ did not have any knowledge of what $\mathrm{HbA}_{1 \mathrm{c}}$ was. $44 \%$ did not experience hypoglyceamia or experienced it very rarely. Diabetic complications were declared by $51.0 \%$ of the patients in the study group. The most common complications included were of cardiac (57\%) or ophthalmic $(43 \%)$ origin.

Sufficient knowledge about diabetes was declared by $37 \%$ of the respondents. $61 \%$ participated in a training concerning diabetes treatment and health conscious behaviour. An average level of the usability of a diabetes training amounted to $3.84 \pm 1.24$ on a scale from 1 to 5 , which makes it a mediocre one. In the material analysed $40 \%$ of the patients declared to remain under psychiatric care. $25 \%$ of the diabetic patients were diagnosed with depression. Among the symptoms noted by the patients the respondents enumerated fatigue, lack of energy, lack of motivation to make an effort (60\%). It was often noted that the patients experienced concentration and memory problems $(47 \%)$, insomnia, prolonged sleep (43\%) or sadness, emptiness, and dejection (43\%). 54\% of the patients in study expressed their opinion concerning diabetes being a factor intensifying depression. Lack of such impact was stated by $10 \%$. A group of $36 \%$ of patients did not know whether diabetes had any influence on the intensity of the depression symptoms. The most common factor causing discomfort (73\%) was the sense of incurability. Approximately half of the patients pointed hypo- and hyperglycaemia and the complications involved as the factors causing discomfort (52\%). $48 \%$ stated that it was the fear of gaining weight, $47 \%$ — blood glucose controls and insulin injections as well as the cost of the treatment. The need for frequent visits at the Diabetic Clinic were of less important (18\%). The 


\begin{tabular}{|c|c|c|c|c|c|c|c|c|c|c|}
\hline & & \multicolumn{9}{|c|}{ Type of diabetes } \\
\hline & & \multicolumn{2}{|c|}{$\begin{array}{c}\text { Type } 1 \\
\text { diabetes }\end{array}$} & \multicolumn{2}{|c|}{$\begin{array}{c}\text { Type } 2 \\
\text { diabetes }\end{array}$} & \multicolumn{2}{|c|}{$\begin{array}{c}\text { Insulin } \\
\text { treated type } \\
2 \text { diabetes }\end{array}$} & \multicolumn{2}{|c|}{$\begin{array}{c}\text { Gestational } \\
\text { diabetes }\end{array}$} & \multirow[t]{2}{*}{ p } \\
\hline & & $\mathbf{N}$ & $\%$ & $\mathbf{N}$ & $\%$ & $\mathbf{N}$ & $\%$ & $\mathbf{N}$ & $\%$ & \\
\hline \multirow[t]{2}{*}{ Sadness, emptiness, dejection } & No & 20 & 52.6 & 13 & 56.5 & 17 & 53.1 & 7 & 100.0 & 0.1231 \\
\hline & Yes & 18 & 47.4 & 10 & 43.5 & 15 & 46.9 & 0 & 0.0 & \\
\hline Lower self-esteem, sense of being of little & No & 24 & 63.2 & 18 & 78.3 & 19 & 59.4 & 7 & 100.0 & 0.1161 \\
\hline value, uselessness & Yes & 14 & 36.8 & 5 & 21.7 & 13 & 40.6 & 0 & 0.0 & \\
\hline \multirow[t]{2}{*}{ Difficulty in making decisions, powerlessness } & No & 29 & 76.3 & 22 & 95.7 & 21 & 65.6 & 7 & 100.0 & 0.0253 \\
\hline & Yes & 9 & 23.7 & 1 & 4.3 & 11 & 34.4 & 0 & 0.0 & \\
\hline Stopping diabetes control, forgetting about & No & 33 & 86.8 & 21 & 91.3 & 27 & 84.4 & 7 & 100.0 & 0.6506 \\
\hline medicaments, injections, indifference & Yes & 5 & 13.2 & 2 & 8.7 & 5 & 15.6 & 0 & 0.0 & \\
\hline \multirow[t]{2}{*}{ Loss of interest in pleasure } & No & 27 & 71.1 & 17 & $73.9 \%$ & 21 & $65.6 \%$ & 7 & $100.0 \%$ & 0.3305 \\
\hline & Yes & 11 & 28.9 & 6 & 26.1 & 11 & 34.4 & 0 & 0.0 & \\
\hline \multirow[t]{2}{*}{ Avoiding meeting family and friends } & No & 29 & 76.3 & 19 & 82.6 & 22 & 68.8 & 7 & 100.0 & 0.2910 \\
\hline & Yes & 9 & 23.7 & 4 & 17.4 & 10 & 31.3 & 0 & 0.0 & \\
\hline Fatigue, lack of energy, lack of motivation & No & 12 & 31.6 & 12 & 52.2 & 15 & 46.9 & 1 & 14.3 & 0.1645 \\
\hline to make an effort & Yes & 26 & 68.4 & 11 & 47.8 & 17 & 53.1 & 6 & 85.7 & \\
\hline Insomnia or prolonged sleep — changes & No & 22 & 57.9 & 14 & 60.9 & 17 & 53.1 & 2 & 28.6 & 0.4808 \\
\hline in night habits & Yes & 16 & 42.1 & 9 & 39.1 & 15 & 46.9 & 5 & 71.4 & \\
\hline \multirow[t]{2}{*}{ Concentration and memory problems } & No & 20 & 52.6 & 14 & 60.9 & 14 & 43.8 & 5 & 71.4 & 0.4527 \\
\hline & Yes & 18 & 47.4 & 9 & 39.1 & 18 & 56.3 & 2 & 28.6 & \\
\hline \multirow[t]{2}{*}{ Loss of appetite or abnormal appetite } & No & 30 & 78.9 & 16 & 69.6 & 19 & 59.4 & 3 & 42.9 & 0.1546 \\
\hline & Yes & 8 & 21.1 & 7 & 30.4 & 13 & 40.6 & 4 & 57.1 & \\
\hline Suicidal thought, taking my own life would & No & 32 & 84.2 & 20 & 87.0 & 25 & 78.1 & 7 & 100.0 & 0.5114 \\
\hline be the best solution to my problems & Yes & 6 & 15.8 & 3 & 13.0 & 7 & 21.9 & 0 & 0.0 & \\
\hline
\end{tabular}

quality of life was evaluated as very bad by $15 \%$ of the respondents and $9 \%$ assed the quality as bad. Most often the patients perceived the quality of their life as mediocre (42\%). $23 \%$ of them declared it was good and $11 \%$ as very good. The original study reported that the depression symptoms were experienced by all of the patients with diabetes. The most common symptoms were fatigue, lack of energy, lack of motivation to make an effort.

The study proved that difficulty in decision making and powerlessness occurred significantly more frequently in patients with type 2 diabetes treated with insulin (34.4\%) rather than in type 1 diabetes $(23.7 \%)$ and only in one case of a patient with type 2 diabetes not taking insulin. The discrepancies were statistically significant. An association between depression symptoms and the type of diabetes was not observed (Tab. 1).

The analysis of the data showed that consulting a psychiatrist was declared by $71.4 \%$ of patients with gestational diabetes, $65.2 \%$ of the patients with type 2 diabetes, and $57.9 \%$ of those with type 1 diabetes and $56.3 \%$ of the respondents with type 2 diabetes treated with insulin. The study revealed that $43.6 \%$ of men and $37.7 \%$ of women consulted a psychiatrist. Depression treatment applied to $30.8 \%$ of male and $21.3 \%$ of female patients. The analysis of the data collected in our study showed that diabetic complications occurred in $67.5 \%$ of the patients undergoing psychiatric consultations and $36.7 \%$ of the patients that did not consult a psychiatrist. It was presented that diabetic complications occurred in $84.0 \%$ of the patients who were treated for depression and in $37.3 \%$ of those patients that did not receive any depression treatment.

Our study revealed that it was more common for patients treated for diabetes for over 20 years to consult psychiatrist $(61.5 \%)$. It proved that diabetic patients for over 20 years were treated because of depression more often $(53.8 \%)$, in comparison to treated for diabetes $11-20$ years $(22.9 \%)$ and $7.7 \%$ in patients treated less than 10 years respectively. The evaluation of the study results showed that the level of satisfaction with physician's care among the patients consulting a psychiatrist was 4.38 and did not vary 
significantly from the satisfaction level presented by the patients who were not participating in psychiatric consultations (4.35). Similarly, the level of satisfaction with nursing care did not differ significantly between the patients who consulted a psychiatrist (4.28) and those who did not (4.22). Our study presented that the people who were treated for depression evaluated their level of satisfaction with physician's care at an average level of 4.20, and the patients who did not receive any depression treatment at a level of 4.41 . Similarly, it was not observed that the level of satisfaction with nursing care depended significantly on the depression treatment. It was 4.04 in patients being treated for depression and 4.31 in those not getting any treatment. The study showed that consulting a psychiatrist was not significantly related to either the level of the $24 \mathrm{~h}$ blood glucose or $\mathrm{HbA}_{1 \mathrm{c}}$ result. However it was noted that the respondents undergoing depression treatment had a significantly lower result with lowest daily glucose level of $74 \mathrm{mg} / \mathrm{dL}$ as compared to the respondents who did not receive any depression treatment $(85.91 \mathrm{mg} / \mathrm{dL})$. Some marginal differences pointed that patients treated with depression had higher upper daily glucose level $(236.60 \mathrm{mg} / \mathrm{dL})$, than patinets not treated with depression (219.85 $\mathrm{mg} / \mathrm{dL}$ ). The patients who were treated for depression had also a higher level of $\mathrm{HbA}_{1 \mathrm{c}}$ (7.14) as compared to the patients who did not received depression treatment (6.66). The average level of the $24 \mathrm{~h}$ blood glucose in patients consulting a psychiatrist amounted to $152.56 \mathrm{mg} / \mathrm{dL} \pm 29.93$ and did not vary significantly ( $p=0.8962)$ from the average level of the $24 \mathrm{~h}$ blood glucose in patients who were not consulting their condition with psychiatrist $(154.52 \mathrm{mg} / \mathrm{dL} \pm$ 33.77). Similarly the average blood glucose level in patients being treated for depression $(156.30 \mathrm{mg} / \mathrm{dL}$ $\pm 30.17)$ did not differ significantly $(p=0.5418)$ from the average level of blood glucose in patients without depression treatment $(152.88 \mathrm{mg} / \mathrm{dL} \pm 32.94)$. The results did not confirm a significant association between the level of blood glucose and depression.

\section{Discussion}

Existing publications state that depression symptoms may be observed in aproximatelly $40 \%$ of people being hospitalized due to somatic diseases. The frequency of the symptoms, however, varies depending on the condition, for instance in patients with ischemic heart disease it is $17-20 \%$, stroke $-65 \%$, Parkinson's disease - aprox. $35 \%$, pain - over $50 \%$, malignancies - 20-40\%, diabetes - 10-27\% [7-12]. In our studies patients with type 1 and type 2 diabetes patients taking insuline, constituted the largest groups, with $38 \%$ and $32 \%$ respectively. The remaining patients suffered from diabetes but did not take insuline (23\%) and gestational diabetes (7\%). Authors claim that among the depression risk factors in case of patients with diabetes the most common ones are: young age, bad financial situation, low education level, being single and being female $[13,14]$. Depression constitutes also an independent risk factor in terms of type 2 diabetes $[15,16]$. One of the meta-analysis evaluating the relation between depression and diabetes has shown that the risk of diabetes is $37 \%$ higher in patients with depressive disorders than in a healthy population [17]. Significantly more often diabetes occurs in patients with mental disorders. It is often one of the side effects of the antipsychotic drugs. A proper choice of medicines taking into consideration possible risk factors for diabetes and obesity as well as proper treatment control should allow to prevent the disorders from appearing or early diagnosis and adequate treatment modification [18]. It is partly due to the fact that some of the diabetes risk factors such as lack of physical activity, obesity, smoking are observed more frequently in patients suffering from depression [19]. What should also be considered is the direct negative influence of depression disorders on glucose metabolism, for instance increased contra regulating hormonal excretion, disorders of glucose transport, and increased activity of inflammatory factors that increase insulin resistance $[20,21]$. Moreover, patients with depression share a tendency to neglect self-control (taking drugs regularly, glucose level control, diet and regular physical activity), which is responsible for worse metabolic balance in diabetes leading to chronic complications developement [22, 23]. Our study presents that all of the respondents declared testing blood glucose level using a glucometer a few times a day. It may be assumed that patients with diabetes have a big awareness of how important self-control is in the course of treatment. On the other hand, some studies suggest that low awareness is associated with insufficient self-control and increased number of complications in the course of diabetes [24]. According to DiMatteo et al disability resulting from the complications that make everyday life difficult may evoke as well as intensify depression and diminish the body response to antidepressants [23]. Kurowska et al reports that people complying with the prescribed diet shared a definitely lower level of depression symptoms ( $p<0.0278$ ). The level of depression was significantly higher in patients who were unemployed and in those being on pension, social benefits $(p<0.0305)$ [25].

Patients with depression or a comorbid chronic disease are three times more likely not to obey the therapeutic guidelines than the people without such disorders [26]. It is very difficult for a patient suffering 
from both depression and diabetes to practice sports regularly, to take medicines in compliance with the physician's orders or to stop smoking. A direct association between depression and diabetes is constant and independent from socioeconomic status or cultural origin $[27,28]$. The respondents often visit the physicians in specialist clinics. Our reports show that results of $24 \mathrm{~h}$ blood glucose measurement were not satisfying; the lowest level was $82.93 \mathrm{mg} / \mathrm{dL}$ and the highest one $-224.54 \mathrm{mg} / \mathrm{dL}$. Testing the $\mathrm{HbA}_{1 \mathrm{c}}$ level in the previous year was declared by less than a half of the respondents (49\%) including 44 people from this group who shared their results. The results of $\mathrm{HbA}_{1 \mathrm{c}}$ ranged from $5.0-10.0 \%$ with the half of them being less than $7.0 \%$. This indicates a rather good level of treatment management. Unfortunately the largest percentage of the respondents did not have $\mathrm{HbA}_{1 \mathrm{c}}$ testes (26\%) and a large group did not even know what it was (25\%). This may be a result of many factors such as physician's incompetency or patients' hesitation concerning performing the test. The literature specifies two, according to the authors, types of fear that the diabetic patients share: a fear of hypoglycaemia and a fear of long term complications. Fear often has negative impact on patient's activity. It also can worsen the metabolic imbalance in the course of diabetes. As a consequence the condition of the patient may get worse. The results have shown that there is a chance of obtaining better results of depression treatment in patients with type 2 diabetes with treatment of the emotional disorders [28]. Majchrzak et al showed that the type of personality of a patient with diabetes impacts the prevalence of depression symptoms and is connected to the level of metabolic balance of diabetes in terms of lipid profile [29]. Kurowska et al reported that the average level of illness acceptance (AIS) was 25.16 in therir study group, which proved that there is an average acceptance among the respondents. Standard deviation amounted to $26.4 \%$ of the mean value, which meant that the AIS results were very much diversified. A definite acceptance was declared by $28.6 \%$ of the patients in the study [25]. Kurpas et al report that diabetic patients obtained an average level of illness acceptance (25.76 \pm 10.34$)$ [30] and Haor et al claim the average result amounted to $25.99 \pm 10.34$ [31]. It was confirmed in our study where not many people (18\%) fully accepted their illness. Slightly more (29\%) got used to the illness. Moreover, the discomfort accompanying the illness was the result of the sense of its incurability. The complications and lack of perspective for a complete recovery is the most important factor causing depression in patients with chronic illness.
Patients with diabetes experience depression disorders. They are usually caused by many factors. Both hypoglycaemia and hyperglycaemia are exceptionally unpleasant. Its sudden appearance does not only cause discomfort but also evokes fear of complications. Diabetic patients who loose conscience while being hypoglycaemic face many other dangers which may result in injuries as well as death itself. The fear of hypoglycaemia causes a massive stress in those patients even during everyday activities such as shopping, commuting or going to the doctor. Often those patients stay at home to avoid possible dangers. Life with diabetes is not easy and often leads to various neurotic disorders which in fact may result in depression. Therefore, it is recommended to raise awareness among the diabetic patients about such disorders and their prevention as well as psychological treatment which should commence as soon as the symptoms occur. Specialists in this area as well as patients' relatives, colleagues and people from the nearest environment would be of a great support for those patients. Zimmet et al emphasise that depression is a significant predictor of low health awareness and depression diagnostics should be developed and widely implemented [2].

\section{Conclusion}

All of the diabetic patients claimed they observed depression symptoms. More men than women admitted they were consulting a psychiatrist, however, the patients who suffered diabetic complications are more likely to consult a psychiatrist or undergo depression treatment. Patients suffering from diabetes for a longer period of time were more likely to consult a psychiatrist which means that the longer the illness is the higher the risk of depression.

Blood glucose fluctuations may influence depression symptoms in patients suffering from diabetes. No statistical significance between depression and the levels of $\mathrm{HbA}_{1 \mathrm{c}}$ was observed in the study.

\section{Conflict of interest}

The authors declare no conflict of interests.

\section{REFERENCES}

1. Wojciechowski P. Edukacja w cukrzycy. Raport diabetologiczny 2015; 1: 18-42.

2. Zimmet PZ, Magliano DJ, Herman WH, Shaw JE. Diabetes: a 21st century challenge. The Lancet Diabetes \& Endocrinology 2014; 2: 56-64.

3. Janeczko D. Epidemiologia chorób układu krążenia u chorych na cukrzycę. Kardiologia Na Co Dzień 2007; 2: 12-16. 
4. Karolina J, Jaślikowska U, Zbrojkiewicz M, Ślusarska B et al. Czynniki związane z występowaniem depresji u osób dorosłych. Przegląd systematyczny literatury polskiej w latach 2009-2014. Journal of Education, Health and Sport. 2016; 6: 297-318.

5. Katon WJ. Clinical and health services relationships between major depression, depressive symptoms, and general medical illness. Biol Psychiatry 2003; 54: 216-226.

6. Anderson RJ, Freedland KE, Clouse RE, Lustman PJ. The prevalence of comorbid depression in adults with diabetes: a meta-analysis. Diabetes Care. 2001; 24: 1069-1078.

7. Carney R, Freedland K, Miller G, Jaffe A. Depression as a risk factor for cardiac mortality and morbidity. A review of potential mechanisms. Journal of Psychosomatic Research 2002; 53: 897-902.

8. Rudisch B, Nemeroff C. Epidemiology of comorbid coronary artery disease and depression. Biological Psychiatry 2003; 54: 227-240.

9. Ziółkowska-Kochan M, Pracka D. Depresja po udarze mózgu. Psychiatria w Praktyce Ogólnolekarskiej 2003; 3: 203-208.

10. Wichowicz H, Sławek J, Derejko M, Cubała WJ. Factors associated with depression in Parkinson's disease: a cross-sectional study in a Polish population. European Psychiatry 2006; 21: 516-520.

11. Nowicki A, Rządkowska B. Depresja i lęk u chorych z nowotworami złośliwymi. Współczesna Onkologia 2005; 9: 396-403.

12. Potyralska MM, Krawczyk AM. Depresja u osób z cukrzycą typu 2 - współwystępowanie, implikacje kliniczne i terapeutyczne. Wiadomości Lekarskie 2007; 60: 449-453.

13. Lustman PJ, Griffith LS, Clouse RE, Cryer PE. Psychiatric illness in diabetes mellitus: relationship to symptoms and glucose control. J Nerv Ment Dis 1986; 174: 736-742.

14. Everson SA, Maty SC, Lynch JW, Kaplan GA. Epidemiologic evidence for the relation between socioeconomic status and depression, obesity, and diabetes. J Psychosom Res 2002; 53: 891-895.

15. Musselman DL, Betan E, Larsen H, Phillips LS. Relationship of depression to diabetes types 1 and 2: epidemiology, biology, and treatment. Biol Psychiatry 2003; 54: 317-329.

16. Eaton WW, Armenian H, Gallo J et al. Depression and risk for onset of type II diabetes: a prospective population-based study. Diabetes Care 1996; 19: 1097-1102.

17. Carnethon MR, Biggs ML, Barzilay Jl et al. Longitudinal association between depressive symptoms and incident type 2 diabetes mellitus in older adults: the Cardiovascular Health Study. Arch Intern Med 2007; 167: 802-807.
18. Duda-Sobczak A, Wierusz-Wysocka B. Diabetes mellitus and psychiatric diseases. Psychiatria Polska 2011; 4: 589-598.

19. Katon W, von Korff M, Ciechanowski P et al. Behavioral and clinical factors associated with depression among individuals with diabetes. Diabetes Care 2004; 27: 914-920.

20. Talbot F, Nouwen A. A review of the relationship between depression and diabetes in adults: is there a link? Diabetes Care 2000; 23: 1556-1562.

21. Kinder LS, Kamarck TW, Baum A, Orchard TJ. Depressive symptomatology and coronary heart disease in type I diabetes mellitus: a study of possible mechanisms. Health Psychol 2002; 21: 542-552.

22. Lustman PJ, Clouse RE. Depression in diabetic patients: the relationship between mood and glycemic control. J Diabetes Complic 2005; 19: 113-122.

23. DiMatteo MR, Lepper HS, Croghan TW. Depression is a risk factor for noncompliance with medical treatment: meta-analysis of the effects of anxiety and depression on patient adherence. Arch Intern Med 2000; 160: 2101-2107.

24. Schillinger D, Grumbach K, Piette J et al. Association of health literacy with diabetes outcomes. Journal of the American Medical Association 2002; 288: 475-482.

25. Kurowska K, Strzesak E, Głowacka M, Felsmann M, Ponczek D. Depresyjność a poczucie koherencji u osób z rozpoznaniem typu 2 cukrzycy. Psychogeriatria Polska 2009; 6: 1-7.

26. Lerman I, Lozano L, Villa AR et al. Psychosocial factors associated with poor diabetes selfcare management in a specialized center in Mexico City. Biomed Pharmacother 2004; 58: 566-570.

27. Park $H$, Hong $Y$, Lee $H$ et al. Individuals with type 2 diabetes and depressive symptoms exhibited lower adherence with self-care. J Clin Epidemiol 2004; 57: 978-984.

28. Abrahanian $\mathrm{H}$, Hofmann $\mathrm{P}$ et al. Diabetes mellitus and co-morbid depression: treatment with milnacipran results in significant improvement of both diseases (results from the Austrian MDDM study group) Neuropsychiatr Dis Treat 2009; 5: 261-266.

29. Majchrzak A, Pietrzykowska E, Zozulińska-Ziółkiewicz D, Wierusz-Wysocka B. Wpływ typu osobowości na poziom depresji i wyrównanie metaboliczne u chorych na cukrzycę typu 1. Diabetologia Praktyczna 2009; 10: 85-91.

30. Kurpas D, Kusz J, Jedynak T et al. The acceptance level of chronic diseases among patients. Family Medicine \& Primary Care Review 2012; 14: 396-398.

31. Haor B, Gołębiewska A, Głowacka M, Rezmerska L. Selected aspects of acceptance of chronic disease in patients of type 2 diabetes. Zeszyty Naukowe WSHE. 2013; XXXVII: 93-104. 